\title{
Bioaccumulation of heavy metals in fish sourced from environmentally stressed axis of River Niger: Threat to ecosystem and public health
}

\author{
Ezeonyejiaku Chigozie Damian, Nwuba Lucy Afulenu², Obiakor Maximilian Obinna ${ }^{3,}$, \\ Okonkwo Chidumeje Ndidi ${ }^{3}$ \\ ${ }^{1}$ Department of Zoology, Nnamdi Azikiwe University Awka, Anambra Nigeria \\ ${ }^{2}$ Department of Fisheries and Aquaculture, Nnmadi Azikiwe University Awka, Anambra Nigeria \\ ${ }^{3}$ School of Environmental and Rural Science, University of New England, Armidale, NSW, 2351, Australia
}

\section{Email address:}

mobiako2@une.edu.au (Obiakor M. O.)

\section{To cite this article:}

Ezeonyejiaku Chigozie Damian, Nwuba Lucy Afulenu, Obiakor Maximilian Obinna, Okonkwo Chidumeje Ndidi. Bioaccumulation of Heavy Metals in Fish Sourced from Environmentally Stressed Axis of River Niger: Threat to Ecosystem and Public Health. International Journal of Environmental Protection and Policy. Vol. 2, No. 4, 2014, pp. 126-131. doi: 10.11648/j.ijepp.20140204.11

\begin{abstract}
Pollution of freshwater ecosystems is alarmingly becoming high in Nigeria with attendant public health effects on the dependent populations. Fish, a source of protein with pronounced placement on local food menu is now considered an important dietary threat of heavy metal toxicity via consumptions. Bioaccumulation of heavy metals (copper, zinc and lead) in Silver catfish (Schilbe intermedius) from River Niger was conducted. The Fish samples were collected from different sites of Onitsha axis of the River Niger owing to their environmental stresses. Samples were analyzed for heavy metal (copper- $\mathrm{Cu}$, zinc- $\mathrm{Zn}$, and lead- $\mathrm{Pb}$ ) concentrations in muscle tissues using the Atomic Absorption Spectrophotometer (AAS) and compared with Food and Agriculture Organization safe limits. Margin of exposure (MOE) was estimated to measure the potential public health risk of consuming the contaminated fish. The concentrations of heavy metals $(\mathrm{Cu}-8.92 \pm 4.748, \mathrm{Zn}-0.36 \pm 0.249$, and $\mathrm{Pb}-2.689 \pm 1.505)$ observed were significant $(\mathrm{P}<.05)$ with diversity in different experimental locations and $\mathrm{Cu}$ recording highest pooled mean concentrations. The trend of the metal occurrences was $\mathrm{Cu}>\mathrm{Pb}>\mathrm{Zn}$. Statistical Pearson moment correlation analysis showed that the concentrations of heavy metals detected were independent of the weight of sampled fish for zinc but was positively correlated for copper and lead. Relating the mean metal concentrations obtained in the study with Food and Agriculture Organization standard for fish muscles indicated that mean concentrations of copper, zinc and lead are far above safe margins for human consumption except the fish sourced from sites $\mathrm{A}_{4}$ and $\mathrm{A}_{9}$ for lead and zinc, respectively. Margin of exposure was below one and tentatively considered not to be of risk to public health. However, there is considerable contamination of the Silver catfish from the River Niger with heavy metals. It is recommended that substantial attention be paid to the heavy metal levels in freshwater fishes from the river. Measures should be put in place to regulate the indiscriminate dredging activities, discharge of raw sewage and industrial effluent into the river and regular public health check on the level of heavy metals among the populace in the communities that border the area should be employed.
\end{abstract}

Keywords: $\mathrm{Cu}, \mathrm{Zn}, \mathrm{Pb}$, Bioaccumulation, Silver Catfish, River Niger, Freshwater, Onitsha Axis, Nigeria

\section{Introduction}

Chemical contamination of aquatic ecosystem is unquestionably a global environmental problem. With the increasing anthropogenic activities, toxic residues are continuously mobilized from different channels to the water environment. In addition to the existing substances, emerging elements and chemicals are produced for industrial, domestic and agricultural applications and most of them are non-biodegradable. However, they are redistributed in various environmental media at different time frames. Among these chemicals are heavy metals. 
Heavy metals are those element on the periodic table with atomic number from 22 to 34 (titanium to selenium), 40 to 52 (zirconium to tellurium) and 72 to 83 (Hafnium to Bismuth) [1]. They occur naturally in the ecosystem with large variation in concentration. Conversely, anthropogenic activities have added a lot of these metals into the environment [2]. Although many organisms including man require varying amount of these metal such as cobalt, manganese, iron, copper, molybdenum and zinc in traces, excessive levels can be harmful to organisms [2]. Notwithstanding that many heavy metals are considered as essential macro and micro elements especially at nonadverse effect levels, they can exert negative effect at concentrations encountered in polluted environment [3] both acting singly or jointly in mixtures.

Heavy metals in aquatic environment are currently a major polluting chemicals in both developed and developing countries [4], due to their toxicity and threat to plants and animals. As a result of the contamination capacity of heavy metals, consequent devastating effects are potentially ensued in the receiving environment, thus upsetting the natural ecological balance $[3,5]$. The explicit problem associated with heavy metals in the environment is their accumulation through food chain and persistence in nature [3]. Moreover, many dissolved metals that enter aquatic ecosystem are adsorbed into colloid particles. Certain physicochemical properties enhance their environmental mobility and distribution. At high alkalinity and $\mathrm{pH}$, metals, particularly lead and cadmium are precipitated by forming complexes, which dramatically influence further the metal toxicity [3].

Water-borne metals may alter the physiological and biochemical parameters in fish blood and tissues $[6,7]$ and can result in population melt-down. Fish accumulate chemical xenobiotics, especially those with poor solubility and these chemicals are carried in solution or suspension. Likewise fish have to extract oxygen from the medium by passing enormous volume of water over the gill, skin and digestive tract, which are transported by blood through storage points such as bone or to the liver. They may be stored in extra-hepatic tissue such as fat [3]. Because heavy metal pollution and its management has been a major global concern for environmentalists due to their nonbiodegradable and hazardous nature, this study was conducted with the view to determining the level of some heavy metals (zinc, lead and copper) in Silver catfish (Schilbe intermedius) sampled from Onitsha section of River Niger so as to evaluate their safety for human consumptions. This axis of the River Niger has been under intense pollution of its water and other media ranging from agricultural activities, sand mining and dredging, fishing, disposal of industrial effluents and municipal sewage. Ecology, hydrology, economic and various anthropogenic activities at the upper Niger Basin have been executively summarized by Zwarts et al. [8].

\section{Materials and Methods}

\subsection{Study Location}

The study area was Onitsha axis of River Niger. It is located in Anambra State, Nigeria. The climate is tropical, with annual rainfall exceeding $1500 \mathrm{~mm} /$ annum, temperature between $29-35^{\circ} \mathrm{C}$ and seasonal flooding makes it productive in terms of biodiversity and agricultural uses. The coordinate of the area is latitude $6^{0} 10^{\prime} \mathrm{N}$ and longitude $6^{0} 47^{\prime} \mathrm{E}$. The river rises from Guinea Highland in Southern Guinea and runs crescent through Mali, Niger and then Nigeria, discharging through a massive delta known as Niger Delta, into Gulf of Guinea to the Atlantic Ocean4200 $\mathrm{km}$ from its source $[8,9]$. The water discharge of the Niger River fluctuates significantly over time, which results from both natural and man-made [8]. There are commercial and domestic wastes, drainage and raw sewage from urban areas, and industrial effluents disposals in the river and sand dredging activities.

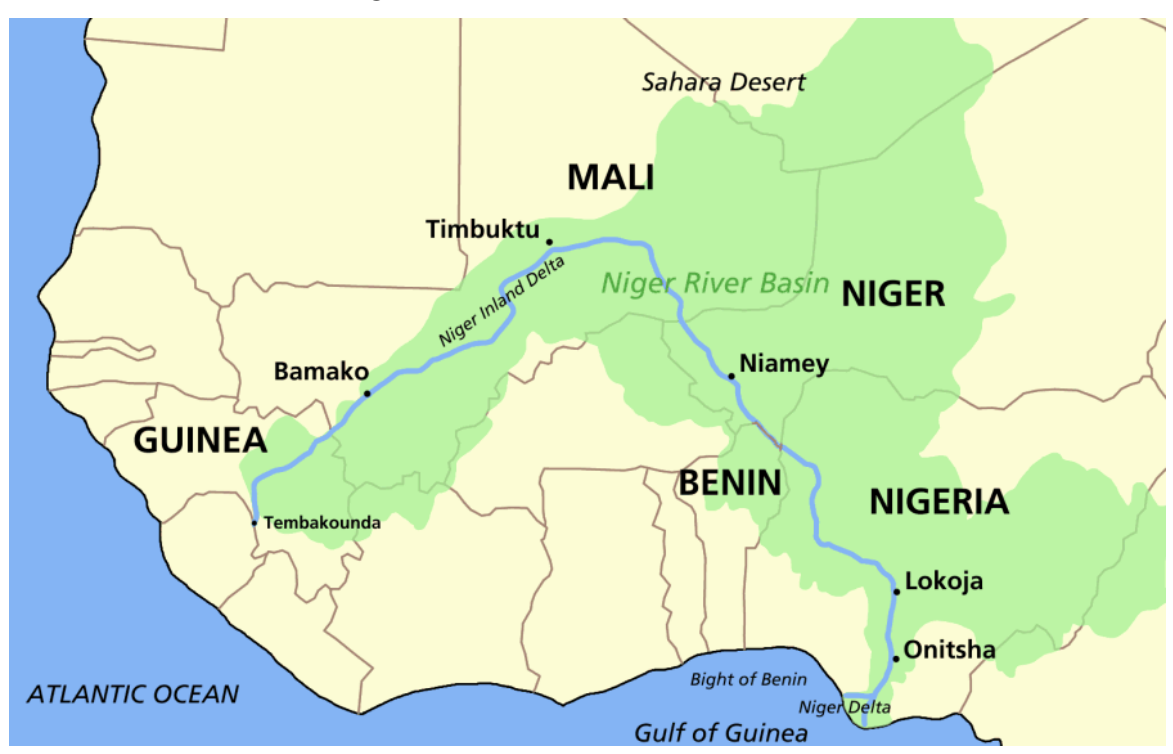

Fig I. Nigeria map extract showing River Niger (in blue string) and its Onitsha axis [10]. 


\subsection{Sample Collection and Identification}

The silver catfish (Schilbe intermedius) used for this study were collected by employing paid local fishermen. They are the preponderant fish in the river and highly consumed by people in the communities bordering the river. The samples were immediately transported alive in a cooler box to the laboratory where they were identified according to Idodo-Umeh [11]. Thirty fish samples each were analyzed from the site for each metal.

\subsection{Weighing and Dissection of Fish Samples}

Fish samples were weighed using digital weighing balance, and values were recorded to the nearest grams. The weighed samples were dissected with dissecting knife to separate the muscle from head/viscera and bone [12].

\subsection{Digestion of Samples and Determination of Metals}

The fish samples were digested following established procedure [13]. The procedure involve grinding a portion of a sample from each fish and weigh $5 \mathrm{~g}$ of each sample into Teflon crucible $10 \mathrm{ml}$ of freshly prepared concentrated $\mathrm{HCL} / \mathrm{HNO}_{3}$ (aqua-regia) in the rations of 3:1 was added to each sample in the Teflon crucibles. The crucibles were covered with watch glass for initial reaction to subside. The samples in the crucibles were heated in the oven at a temperature not exceeding $150^{\circ} \mathrm{C}$ for 2 hours until the solution became clear and completely digested. The samples were cooled and $10 \mathrm{ml}$ of distilled water was added to each sample. The samples were filtered using Whatman's filter paper into $250 \mathrm{ml}$ volumetric flask. The samples were made up to $250 \mathrm{ml}$ with distilled water and used for metal analysis using Atomic Absorption spectrophotometer (AAS). Copper, zinc and lead were determined.

\subsection{Human Risk Measurement}

Risks associated with human consumptions of the potential contaminated fish were calculated by comparing concentrations of the heavy metals quantified in the muscles and Food and Agriculture Organization safe limits. Margin of exposure (MOE) was explored to assess the species-specific risk from consumption of contaminated fish with heavy metals as given by Watanabe et al. [14]:

$$
M O E=\frac{\mathrm{MCC} \times \mathrm{CR}}{\mathrm{BW} \times \mathrm{RfD}}
$$

where $M C C$ was the species-specific mean chemical concentration $(\mathrm{mg} / \mathrm{kg}), C R$ was the consumption rate presumed to be $0.03 \mathrm{~kg} / \mathrm{day}, B W$ was the human body weight assumed to be $70 \mathrm{~kg}$ and $R f D$ was the reference dose for the specific constituent in $\mathrm{mg} / \mathrm{kg}$ [15]. MOE greater than 1 indicates the exposure to a dose higher than the safe daily dose for chronic non-carcinogenic effects. The reference dose value adopted by the United States Environmental Protection Agency [15] and used in this study was: $\mathrm{Zn}=15$; for copper and lead, no information exists as per the RfD values. The metals are classified as human carcinogens with copper and lead categorized under groups $3 \mathrm{a}$ and $2 \mathrm{a}$, respectively $[16,17]$.

\subsection{Statistical Analysis}

Data obtained were analyzed using IBM SPSS statistics, version 22. Descriptive tool was employed to show distribution of the copper, lead and zinc concentrations examined in the muscle tissues and relative weights of the various Silver catfish. Analysis of variance was conducted and multiple comparison among treatment means achieved using Post Hoc Tukey. Degree of association between the weights of the sampled fish and heavy metal concentrations determined in vivo was explored using Pearson-moment correlation analysis as adopted by Okafor [18]. The probability of significance was measured at alpha error of $P<0.05$ and $95 \%$ confidence limit.

Table 1. Heavy metal concentrations in muscle tissues of Silver catfish sourced from Onitsha axis of the River Niger.

\begin{tabular}{|c|c|c|c|c|}
\hline Station codes & Weight (g) & $\mathrm{Cu}(\mathrm{mg} / \mathrm{g})$ & $\mathrm{Zn}(\mathrm{mg} / \mathrm{g})$ & $\mathrm{Pb}(\mathrm{mg} / \mathrm{g})$ \\
\hline $\mathrm{A}_{1}$ & $350 \pm 2.50$ & $11.40 \pm 0.611^{\mathrm{b}}$ & $0.36 \pm 0.021^{\mathrm{c}}$ & $4.37 \pm 0.046^{\mathrm{a}}$ \\
\hline $\mathrm{A}_{2}$ & $300 \pm 10.00$ & $5.70 \pm 0.436^{d}$ & $0.53 \pm 0.031^{\mathrm{b}}$ & $1.13 \pm 0.068^{\mathrm{d}}$ \\
\hline $\mathrm{A}_{3}$ & $295 \pm 2.60$ & $3.75 \pm 0.419^{d}$ & $0.53 \pm 0.027^{\mathrm{b}}$ & $2.12 \pm 0.183^{c}$ \\
\hline $\mathrm{A}_{4}$ & $320 \pm 1.50$ & $16.25 \pm 1.090^{\mathrm{a}}$ & $0.08 \pm 0.010^{\mathrm{d}}$ & $0.00 \pm 0.000^{\mathrm{e}}$ \\
\hline $\mathrm{A}_{5}$ & $360 \pm 1.00$ & $12.10 \pm 0.493^{\mathrm{b}}$ & $0.25 \pm 0.050^{\mathrm{c}}$ & $4.74 \pm 0.050^{\mathrm{a}}$ \\
\hline $\mathrm{A}_{6}$ & $280 \pm 0.58$ & $3.18 \pm 0.151^{\mathrm{d}}$ & $0.60 \pm 0.092^{\mathrm{b}}$ & $1.94 \pm 0.050^{\mathrm{c}}$ \\
\hline $\mathrm{A}_{7}$ & $310 \pm 6.10$ & $6.10 \pm 0.436^{c}$ & $0.33 \pm 0.035^{\mathrm{c}}$ & $1.50 \pm 0.340^{c}$ \\
\hline $\mathrm{A}_{8}$ & $315 \pm 2.50$ & $15.80 \pm 0.551^{\mathrm{a}}$ & $0.18 \pm 0.010^{\mathrm{d}}$ & $3.92 \pm 0.075^{b}$ \\
\hline $\mathrm{A}_{9}$ & $320 \pm 1.00$ & $11.08 \pm 0.326^{\mathrm{b}}$ & $0.00 \pm 0.000^{\mathrm{d}}$ & $4.31 \pm 0.104^{\mathrm{a}}$ \\
\hline $\mathrm{A}_{10}$ & $295 \pm 5.00$ & $3.75 \pm 0.104^{d}$ & $0.34 \pm 0.030^{c}$ & $2.44 \pm 0.050^{c}$ \\
\hline $\mathrm{A}_{11}$ & $310 \pm 1.50$ & $9.00 \pm 0.551^{\mathrm{c}}$ & $0.90 \pm 0.208^{\mathrm{a}}$ & $3.80 \pm 0.448^{b}$ \\
\hline $\mathrm{A}_{12}$ & $299 \pm 0.58$ & $4.10 \pm 0.045^{\mathrm{d}}$ & $0.22 \pm 0.060^{c}$ & $2.00 \pm 0.189^{c}$ \\
\hline FAO safe limit & & 0.03 & 0.03 & 0.0005 \\
\hline
\end{tabular}

Mean values bearing the same superscript along the same column are significantly different $(\mathrm{P}<0.05)$. 


\section{Results}

The analysis of copper, zinc and lead show variable and substantial $(\mathrm{P}<0.05)$ concentrations of the heavy metals at different sites examined in the muscle tissues of Silver catfish of fairly similar live-weight (Table 1). Copper recorded the highest concentrations $(\mathrm{P}<0.05)$ among other metals. The trend of the metal concentration occurrences was: $\mathrm{Cu}>\mathrm{Pb}>\mathrm{Zn}$ at significant levels $(\mathrm{P}<0.05)$ and $95 \%$ confidence limit.

Following the concentrations of the sampled heavy metals in the fish muscles, weight of the fish showed strong positive and significant associations $(\mathrm{P}<0.05)$ with amounts of copper and lead observed at $r^{2}=0.681$ and 0.610 , respectively, while zinc concentrations assumed an inverse and negative association with the weight of test Silver fish species $\left(r^{2}=-0.288\right)$.

The concentrations of the metals in the fish from the study location were all above safe limits stipulated by Food and Agriculture Organization (FAO) for fish except samples sourced from sites $\mathrm{A}_{4}$ and $\mathrm{A}_{9}$ for lead and zinc, respectively, which recorded zero levels (Tables 1 and Figures 2-4). Human risks estimation of fish consumptions contaminated with the sampled heavy metals as based on the margin of exposure (MOE) were negligible for zinc (Table 2). No data apparently exist on reference dose values for copper and lead and their MOE not calculated. All the pooled mean concentrations of the metals were above $(\mathrm{P}<0.05)$ the safe margins (Table 2$)$.

Table 2. Mean $( \pm S D)$ concentrations of heavy metals, FAO safe limits and margin of exposure (MOE) in the muscle tissues of the Silver catfish sourced from Onitsha axis of River Niger

\begin{tabular}{llll}
\hline $\begin{array}{l}\text { Heavy } \\
\text { metals }\end{array}$ & $\begin{array}{l}\text { Concentrations } \\
(\mathbf{m g} / \mathbf{g})\end{array}$ & $\begin{array}{l}\text { FAO safe } \\
\text { limit }\end{array}$ & $\begin{array}{l}\text { Margin of } \\
\text { Exposure }\end{array}$ \\
\hline Copper $(\mathrm{Cu})$ & $8.92 \pm 4.748$ & 0.03 & - \\
Zinc $(\mathrm{Zn})$ & $0.36 \pm 0.249$ & 0.03 & 0.01028571 \\
$\operatorname{Lead}(\mathrm{Pb})$ & $2.689 \pm 1.505$ & 0.0005 & - \\
\hline
\end{tabular}

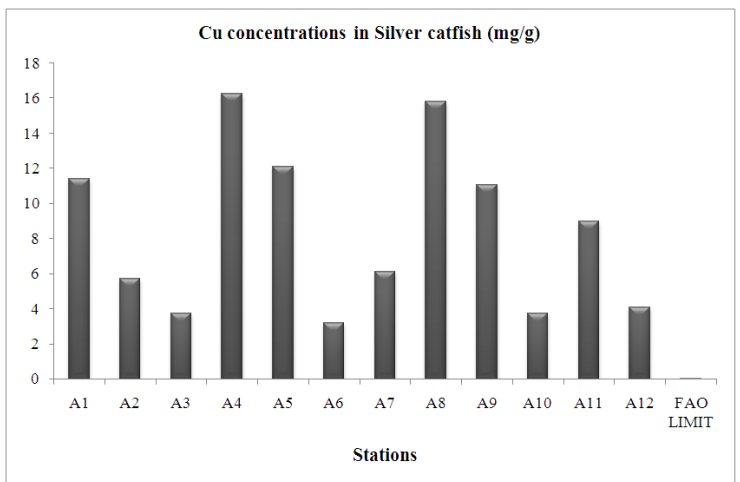

Fig 2. Relative concentrations of copper in Silver catfish to the FAO safe limit

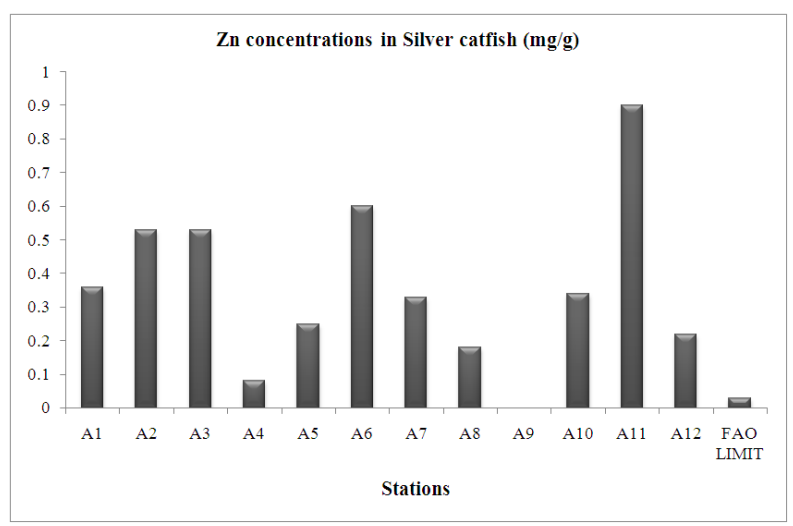

Fig 3. Relative concentrations of zinc in Silver catfish to the FAO safe limit

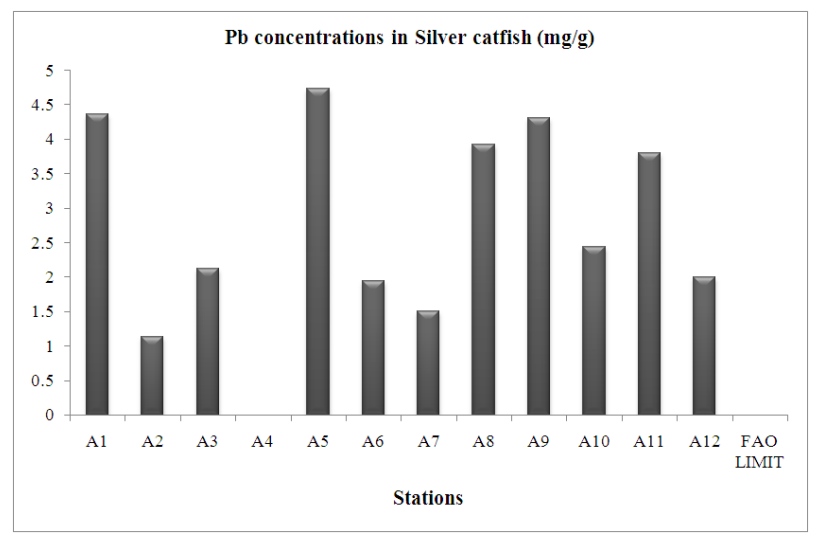

Fig 4. Relative concentrations of lead in Silver catfish to the FAO safe limit

\section{Discussion}

Bioaccumulation of heavy metals in resident fish has been of significant importance in monitoring aquatic pollution. Measurements of copper, zinc and lead in the muscles of Silver catfish showed they bioaccumulated metals amounts. There was significant accumulation of copper in the fish from all the sampled sites and concentrations higher relative to other metals. The high accumulation of copper could be traced to the industrial effluents being discharged into the water to be of high copper origin. However, we cannot comment with high degree of certainty as to the reason of substantial accumulation of copper in the muscle tissues of the fish, which evidently contrasts some earlier reports [12, 19]. These authors recorded higher level of zinc in the muscles of Silver catfish investigated in their studies while the current study has zinc as the least bioaccumulated. Heavy metal bioaccumulation from aquatic environment is highly dependent on a lot of variables that play crucial roles for the entire element uptakes. The factorial facilitators include total amount, bioavailability of each metal in the environmental medium and route of uptake, storage and excretion mechanisms [20] thus, the less available it is the less it will be accumulated. Aquatic lives are exposed to 
single and joint contaminants primarily by oral and dermal routes. Surrounding water constitutes the principal medium of bio-uptakes of heavy metals for fish, which occurs either passively or facilitated uptake [21].

Trophic transfer of heavy metals can occur with consequential high accumulation of the substances in respective organisms at that trophic level with a particular functional group. This phenomenon could not be ruled out with the observations made in this study. Fostner and Wittman [22] in earlier studies described that aquatic micro flora and fauna which constituted fish food are capable of incorporating and accumulating heavy metals in their living cells from their environment. As such, higher concentrations of the heavy are potentially expected at higher trophic levels. However, this would evidently depend on the organisms and metals involved.

Bodyweight is a factor of effect on the accumulation of aquatic contaminants by resident animals. Moreover, the results of this study shows that not all accumulation of heavy metals is dependent on body weight of fish as seen in zinc with inverse association. Ademorati [23] demonstrated that size of organism is one of the major factors influencing bioaccumulation. Studies of Silene and Sandra [24] displayed that bioaccumulation of metals like chromium, cadmium, copper and zinc were independent of body size. We observed copper and lead to be dependent on the bodyweight of the fish sampled. Though contradictory with above reports, however, parallel to reports that copper and zinc concentrations in fish liver displayed significant association with their individual body sizes [24]. Since many factors have been identified to influence bioaccumulation of heavy metals to toxic levels in organisms [20], it may be considered that the variation in the heavy metals concentrations in the fish samples might have been largely influenced by the contamination levels of the study site, implying that high concentrations of metals recorded is probably as a result of the dredging activities and industrial effluents from industries around the area.

Consumptions of heavy metal contaminated fish and other dietary elements are potential threat to public health, even at a low concentration. The accumulation of it can reach a toxic level to the biological systems. Some authors have maintained that there is no uniform standard for most metal concentrations in fish tissues except mercury [25]. Margin of exposure (MOE) observed in this work for zinc was below the reference standard of systemic toxicity for individual and/or population. However, no data were obtained for copper and lead. Classifications of the two metals have been shown to be potential human carcinogens $[16,17]$, though the derivation of their reference dose values are still subject of consideration. Conversely, systemic toxicity resulting from contaminated fish consumption would depend on the amount consumed. The theoretical calculation of the margin of exposure to extrapolate the public health risk in the present work was based on the method adopted by Watanabe et al. [14], which was made in the U.S. Though no reliable data exist on the fish consumption rate and weight of the population living around the Niger River, however, predominant occupation and diet among the poor population there are fishing and fish food, respectively and average weight of the individual around the area would be hypothetically below $70 \mathrm{~kg}$ based on the earlier reconnaissance tour. Differences on fish consumption as a measure of socioeconomic factors and budding risk to community health have been documented in developed countries [14, 26]. Moreover, the concentrations of the selected heavy metals were markedly above safe limits established by Food and Agriculture Organization (FAO) for fish meant for human consumption. The implications remain that the continued consumption of Silver catfish from Onitsha axis of the River Niger poses a serious health risk. Public health effects of dietary intake of fish poisoned with heavy metals have been earlier demonstrated [27, 28]. Zinc may not pose much danger to the public health based on the risk estimation. But this assessment is tentative and simulative on application and might not infer the potentiality of systemic toxicity with utmost degree of certainty on human biological system characterizations. With the observed concentrations of copper and lead, measures are required to reduce the increase in the river as their safety is totally compromised.

Reliable data are needed on the fish consumption rate among the dependent population in proximity to the river. Proactive attention should be paid to the heavy metal levels in freshwater fish from the River Niger by continuous monitoring of heavy metals concentration in edible fish and other aquatic lives. Measures should be put in place to regulate the indiscriminate dredging activities in site, discharge of raw sewage and industrial effluent into the River Niger. These anthropogenic activities are unquestionably enlarging the pollution level of the river. Regular public health checks on the level of heavy metals among the populace in the communities that border the area should be employed in order to safeguard public health and potential metal toxicity.

\section{References}

[1] J.C. Jennette, S.W. Effler, B.G. Wixson, "Mobilization and toxicological aspects of sedimentary contaminants, In: Baker, R.A. (ed)," Contaminants and sediments, "Ann. Arbor Science, vol. 1, 1980, pp.29-44.

[2] J.H. Duffus, "Heavy Metal," IUPAC technical report, vol. 74, 2002, pp. 793-807.

[3] G.A. Dimari, F.I Abdulkarim, J.C. Akan, S.T. Garba), "Metal concentrations in tissues of Bagrus bayad, Clarias lazera and Osteoglosides caught from Alau Dam, Maiduguri, Borno state, Nigeria", American Journal of Environmental Sciences. vol. 4, 2008, pp.379-473.

[4] R.Lloyd, "Pollution and Fresh Water Fish, Cornwalls press, Britain 1192, Pp. 77-86. 
[5] E.O. Farombi, D .A Adelowo, Y.R. Ajimoke, "Biomarker of oxidative stress and heavy metal levels as indicators of environmental pollution in African catfish (Clarias gariepinus) from Ogun, Nigeria", Int. Journal of Environment Res. Public Health, vol. 4,2007, pp. 158-163.

[6] M.O. Obiakor, C.D. Ezeonyejiaku, "Biochemical alterations induced by heavy metal mixture $(\mathrm{Cd}, \mathrm{Cr}$ and $\mathrm{Pb})$ on the Level of vitamin $\mathrm{E}$ and glycogen in the liver. Natural Environment, vol. 1, 2013, pp. 28-32.

[7] S.A. Mansour, M.M. Sidky, "Ecotoxicological studies of heavy metals contaminating water and fish from Fayoum Governorate Egypt, "Food Chemistry, vol. 78, 2002, pp. 1522.

[8] L.Zwarts, P.vanBeukering, B. Bakarykone, E. Wymenga, "The Niger, a lifeline. Effective water management of the Upper Niger Basin,” 2005, ISBN 90-807150-6-9

[9] R.L. Welcomme, H. Dumont, "The Niger River system, In B Davies \& K. Walker (Eds)," The Ecology of River Systems",vol. 60, 1986. pp. 9-59, Springer Netherlands.

[10] Nigeria Basin Authority "http://en.wikipedia.org/wiki/Niger_Basin_Authority, 2013.

[11] Idodo-Umeh, "Ecology of West African Fishes. Idodo-Umeh West African Publishers Limited. 2003, pp. 104-106.

[12] J.C, Nnaji, A. Uzairu, M.F. Harrison, M. Balarabe, "Heavy metals in muscles of Oreochromis niloticus and Bagrus bayad of River Galma, Zaria, Nigeria,"Biological and Environmental Sciences Journal for the Tropics, vol. 4, 2007, pp.181-189.

[13] F. E. Olaifa, A.K. Olaifa, T.E. Nwude, "Lethal and sublethal effect of copper to the African catfish (Clarias gariepinus) juveniles,"African Journal of biomedical Research, vol. 7, 2004, pp.65-70.

[14] K.H. Watanabe, F.W. Desimone, A. Thiyagarajah, W.R. Hartley, A.E. Hindrichs, "Fish tissue quality in the Lower Mississippi River and health risks from fish consumption,"Sci. Total Environ., vol. 302, 2003, pp. 109126.

[15] EPA,"Integrated Risk Information System, USA, "Environmental Protection Agency, Retrieved from http://www.epa.gov/iris 2001.
[16] IARC, "IARC monograph on the evaluation of carcinogenic risks to humans, "WHO, International Agency for Research on Cancer, vol. 83, 2004.

[17] IARC, "IARC monograph on the evaluation of carcinogenic risks to humans, "WHO, International Agency for Research on Cancer, vol. 82, 2002.

[18] L.C.Okafor, “Biometry”.Geelink Publishers Onitsha, Anambra. 2000, pp. 68-188.

[19] U B. Nsikak, "Cadmium, copper, lead, and zinc levels: In Bonga Shad (Ethamalosa fimbriata and Bagrus bayad) caught from Imo River, Nigeria, "American Journal of Food Technology, vol. 2, 2007, pp.48-54.

[20] P.M. Chapman, H.E.Allen, K. Godtfredsen, M.N.Z'Graggen, "Policy analysis, peer reviewed: evaluation of bioaccumulation factors in regulating metals,"Environmental Science \& Technology, vol. 30, 1996,pp. 448A-452A.

[21] L. Regan,"The design of metal-binding in proteins: Review”Annu. Rev. Biophys. Biomol Structure. vol.22, 1993, pp. 257-281.

[22] U. Fostner,G.T. Wittman, "Metal Pollution in Aquatic Environment. Springer Links, New York, 1981, p.486

[23] C.M Ademorati, "Environmental Chemistry and Toxicology. Foludx press Ibadan, 1996, p. 215.

[24] D.C. Silene,M.H. Sandra, "Evaluation of trace metals (Cd, $\mathrm{Cr}, \mathrm{Cu}, \mathrm{Zn}$ ) in tissues of commercially important Leporinus obstusidens from Guiba Lake, Southern Brazil, "Brazarch. Biol. Technol, vol. 52, 2009, pp. 247-250.

[25] J.Burger,M. Gochfeld,"Heavy Metals in Commercial Fish in New Jersey. Environmental Research, vol.99, 2005, pp. 403412.

[26] J. Burger, K.F. Gaines, M. Gochfeld,), "Ethnic Differences in Risk from Mercury among Savannah River fishermen. Risk Anal., vol. 21, 2001, pp. 533-544.

[27] G.J. Fosmire, "Zinc Toxicity. Am. J. Clin. Nutr. vol. 51, 1990, pp. 225-227.

[28] M.O. Ogwuegbu, W. Mahanga, "Investigation of lead concentration in the blood of people in the copper belt of Zambia. J. Environ., vol. 1, 2005, pp. 66-75. 